\title{
WILLINGNESS TO RENT PUBLIC LAND FOR ROTATIONAL GRAZING: THE IMPORTANCE OF RESPONSE BEHAVIOR
}

\author{
DANIEL F. MOONEY* \\ Department of Agricultural and Resource Economics, Colorado State University, Fort Collins, Colorado \\ COURTNEY BOLINSON \\ Robinson Evaluation, Madison, Wisconsin \\ BRADFORD L. BARHAM \\ Department of Agricultural and Applied Economics, University of Wisconsin-Madison, Madison, Wisconsin
}

\begin{abstract}
Ex ante analyses of agricultural practices often examine stated preference data, yet response behavior as a potential source of bias is often disregarded. We use survey data to estimate producers' willingness to rent public land for rotational grazing in Wisconsin and combine it with information on nonrespondents to control for nonresponse and avidity effects. Previous experience with managed grazing and rental decisions influenced who responded as well as their rental intentions. These effects do not produce discernable bias but still encourage attention to this possibility in other ex ante contexts. Land rental determinants and willingness-to-pay estimates are also related to grazing initiatives.
\end{abstract}

Keywords. Avidity, beef cattle, contingent valuation, management-intensive grazing, nonresponse, stated preferences, survey bias

JEL Classifications. Q15, Q16, Q18

\section{Introduction}

Grazing has been widely practiced on public land in the United States for more than a century. For example, the U.S. Bureau of Land Management presides over

\footnotetext{
The authors thank the U.S. Department of Agriculture (USDA), National Agricultural Statistics Service regional field office in Des Moines, Iowa, for data support. They also thank Tom Cox, Brian Gould, Randy Jackson, Laura Paine, and Mark Rickenbach for helpful comments on this research and acknowledge the USDA National Institute of Food and Agriculture Hatch Project WIS01785, USDA North Central Region Sustainable Agriculture Research and Education Project GNC15-209, and U.S. Department of Energy (DOE) Great Lakes Bioenergy Research Center (DOE Office of Science BER DEFC02-07ER64494) for financial support.

*Corresponding author's e-mail: daniel.mooney@colostate.edu
} 
245 million acres of land and authorizes livestock grazing on nearly two-thirds of that area (U.S. Bureau of Land Management, 2016). Since the Taylor Grazing Act in 1935, private ranchers have paid to graze public lands, but certain aspects remain contentious. Historically, user fees have not covered the full financial costs of program management (Gardner, 1997). In addition, these programs possibly affect wild animal populations that compete with cattle for habitat or are perceived as a threat (Frisina and Morin, 1991; Whittlesey, Huffaker, and Butcher, 1993). Despite these potential drawbacks, public land stakeholders in other U.S. regions are investigating whether renting public land to private livestock producers for management intensive grazing (MIG) practices such as rotational grazing, mob grazing, or cell grazing could serve as a cost-effective tool for maintaining a stock of productive and diverse public grassland ecosystems (Melkonyan and Taylor, 2013).

From a public land management perspective, MIG practices can complement or replace the need for other costly grassland management tools like burning, mowing, haying, or herbicide that are more traditionally used to counter forest encroachment (Harrington and Kathol, 2009; Sulak and Huntsinger, 2007). The loss of grazing land is a concern because it may pose a threat to regional heritage, rare animal and insect species, upland game habitat, and other cultural and environmental services valued by the public. Disturbances from MIG can also improve soil health and increase species diversity with minimal negative effects on water quality (Barry, 2011; Hubbard, Newton, and Hill, 2004). This aspect is especially important given shrinking conservation budgets have limited the capacity of public agencies to apply conventional management tools.

Rotational grazing-which divides pastures into paddocks with livestock cycled through them based on forage growth, weather, and other factors (Undersander et al., 2011) - is one example of an MIG practice that has recently gained traction in the U.S. upper Midwest. In Minnesota, initiatives by the U.S. Fish and Wildlife Service, Minnesota Department of Natural Resources (DNR), and the Nature Conservancy permitted grazing on nearly 25,000 acres of public land in 2014 with plans to double the amount in coming years (DeVore, 2014). A similar proposed program in Wisconsin remains in the evaluation phase (Johansen, 2017; Robinson, 2017). In Wisconsin, land access is among the most cited challenges for cattle producers (Kloppenburg et al., 2012). Furthermore, overall pasture area has been in decline since 2007 (U.S. Department of Agriculture [USDA], 2013). At the same time, implementation of rotational grazing on private land is increasing, and there are 15 county-level grazing networks (Robinson, 2017). MIG is particularly prevalent on dairy farms that also frequently manage beef cattle (Brock and Barham, 2009). Previous research on rotational grazing as a public land management tool in Wisconsin is sparse. Research that does exist is primarily qualitative and does not address producer interest in renting public lands (Robinson, 2017). 
In this article, we investigate Wisconsin beef cattle producers' willingness to rent public land for rotational grazing. ${ }^{1}$ Economists often use stated preference methodologies to carry out ex ante analyses of new and emerging agricultural production technologies, management techniques, and land use practices. Examples include applications to genetically modified citrus trees (Singerman and Useche, 2017), bioenergy cropping systems (Mooney, Barham, and Lian, 2015; Skevas et al., 2016; Swinton et al. 2017), prescribed grazing (Jensen et al., 2015), Bt Cotton (Hubbell, Marra, and Carlson, 2000; Qaim and de Janvry, 2003), land and water stewardship practices (Cooper, 1997; Cooper and Keim, 1996; Ma et al., 2012), and rbST (recombinant bovine somatotropin) milk production (Barham, 1996). Specifically, we employ contingent valuation (CV) methods to evaluate the factors influencing producers' stated land rental decisions for two pasture types (grass- and shrub-dominant) and to characterize the distribution of associated willingness-to-pay (WTP) values. In doing so, we make two contributions to this literature. First, we explicitly incorporate the effects of survey response behavior into stated preference work on ex ante technology adoption, which mostly ignores the issue. Second, we find that significant variation in WTP estimates arises across producers and land types based on the same factors that influence response behavior. Combined, these findings highlight the importance of attending to the potential effects of response bias.

\section{Stated Preferences, Rotational Grazing on Public Land, and Survey Response Behavior}

As is the case for all voluntary survey research methods, stated preference surveys are vulnerable to response bias (Dalecki, Whitehead, and Blomquist, 1993) with hypothetical bias, nonresponse, and avidity effects particularly relevant to ex ante analyses of agricultural production topics. This study, however, offers several advantages in terms of respondents' prior experiences with main features of the ex ante rotational grazing land rental decision. Our target population already raises beef cattle and is likely knowledgeable about private land market transactions (Paine and Gildersleeve, 2011). They may also be land constrained and therefore have a stake in the potential availability of public land for grazing purposes (Kloppenburg et al., 2012). In contrast, because only some producers currently utilize MIG methods, there may be differences in the level of familiarity with required inputs and in their interest in renting public land specifically for these purposes. In our case, both previous experience with land rental arrangements and MIG can (and do) turn out to be predictors of who chose to respond, as well as factors that influence stated rental decisions.

\footnotetext{
1 Beef cattle have less stringent feed requirements as compared with dairy cows and do not need milking. They can be managed on land farther from the farm more easily and represent the most likely type of livestock to be served by public grazing initiatives in the state.
} 
The value of transactional and land management experiences is that they help respondents make meaningful statements about their intentions to rent land for rotational grazing. This minimizes the potential for hypothetical bias that can arise in valuation contexts that pertain to unfamiliar environmental goods and services (Carson, Flores, and Meade, 2001). Respondents to our survey should therefore be more likely to offer accurate answers to CV scenarios based on their knowledge, relevance, and ongoing commitment to the activities described in the questions (Kling, Phaneuf, and Zhao, 2012; Whitehead et al., 1995). In contrast, nonresponse becomes a concern if those who choose not to respond differ in key characteristics from those who do respond (Edwards and Anderson, 1987; Groves, 2006). Avidity effects similarly arise if individuals with greater interest in a particular issue are more likely to respond to a survey about an issue than those with less interest (Ethier et al., 2000). Missing data on explanatory variables that are not missing at random or missing completely at random are of similar concern (Little, 1998; Tsikriktsis, 2005). In these cases, the response behavior could result in survey data similar to that drawn from a nonrandom sample selection process that targeted participants with more interest.

Nonrandom selection is a well-known specification issue in econometrics (e.g., Heckman, 1979), and several methods exist to control for sample selection bias in the analysis of stated preference data. The first is to use stratified random sampling methods and apply postsurvey sampling weights. To extend inference from respondents to the general population, constructed weights adjust for over- or underrepresentation within strata relative to a known population frame (Mitchell and Carson, 1989; Peress, 2010). This approach assumes that respondents are representative of population members within their respective strata and therefore only partially addresses the potential for bias (Loomis, 1987). A second method for surveys with multiple waves of respondent contacts, such as those following the Dillman method (Dillman, Smyth, and Christian, 2014), is to use late responders as a proxy for nonresponders (Studer et al., 2013). This approach assumes that nonrandom selection issues are more likely to occur when response rates are low (Edwards and Anderson, 1987). Mitigating strategies to increase response rates include improving the salience of the survey, reducing the length of the survey instrument, conducting multiple survey mailings, or offering incentives. Mixed evidence is available on the effectiveness of this approach, with several researchers finding no support for it (Dalecki, Whitehead, and Blomquist, 1993; Lahaut et al., 2003).

A final method is to compare characteristics of survey respondents with nonrespondents. The primary challenge here is that data on nonrespondents are often unavailable or otherwise costly to collect (Hudson et al., 2004). Some studies in this vein collected data on nonrespondents via postsurvey phone calls (Dalecki, Whitehead, and Blomquist, 1993; Whitehead, Groothuis, and Blomquist, 1993). In other cases, and more commonly found in medical settings, researchers have access to a rich sampling frame or matched data sets that contain 
supplemental information on all members of the sample (Groves, 2006). When data on both respondents and nonrespondents are available, probit models with nonrandom selection can be used to test and control for selection bias (Van de Ven and Van Pragg, 1981; Whitehead, Groothuis, and Blomquist, 1993). Edwards and Anderson (1987) outline this approach for use in CV studies, and Messonnier et al. (2000) and Whitehead and Cherry (2007) apply the approach to environmental and energy choices.

Cooper and Keim (1996) applied a selection model to producer demand for water quality improvements in an ex ante context, but recent efforts generally ignore the issue or rely primarily on postsurvey weighting methods. In this article, we exploit information on respondents and nonrespondents to control for response behavior. Our research strategy involves (1) collection of survey data on producer responses to questions about their willingness to rent public lands for rotational grazing and (2) estimation of a bivariate probit model that jointly estimates producers' willingness to rent public grazing land and their survey response decisions. The econometric model ensures that the identification of factors shaping producer willingness to rent public lands accounts for potential bias from nonresponse or avidity effects. Accurately determining these factors is important because they can help land managers and policy makers to site public grazing programs, design effective outreach to potential participants, and estimate program costs.

\section{The Ex Ante Land Rental Decision}

Consider a utility-maximizing producer who chooses whether to rent land for rotational grazing. Consistent with utility maximization, the producer is willing to rent land whenever the expected utility gain from switching to the CV state is positive (Haab and McConnell, 2003). A typical approach to estimating binary $\mathrm{CV}$ choices is the probit model, where the utility difference between $\mathrm{CV}$ and non-CV states is explained by the $\mathrm{CV}$ offer price and other factors thought to influence the decision and then transformed into a probability using properties of the cumulative normal distribution function (Hanemann, 1984). Because this model relies on survey data voluntarily provided by real decision makers, we also incorporate the potential effects of response behavior.

The decision to respond to a mail survey can similarly be cast in a random utility maximization framework. An assumption implicit in studies that disregard response behavior is that the expected utility of responding is a random variable not explained by factors that also influence the outcome of interest. In the absence of such effects, inferences based on the respondent sample can be extended to the population of interest. However, if the outcome and selection choices are correlated, then avidity or nonresponse behavior can result in nonrandom selection (positive or negative) that potentially leads to biased estimates for 
the outcome equation. In this case, extrapolating inferences from the sample to the population of interest could result in misleading conclusions about the significance and magnitude of certain factors.

We therefore analyze Wisconsin beef producers' stated land rental decisions using a probit model with nonrandom selection to account for the potential effects of response behavior (Van de Ven and Van Pragg, 1981). The bivariate model yields consistent parameter estimates under nonrandom selection and consists of (1) a binary outcome equation that explains producer willingness to rent land for rotational grazing and (2) a binary selection equation that explains survey response behavior. The model we employ is the following:

$$
\begin{aligned}
\operatorname{RENT}_{i} & =\left\{\begin{array}{l}
1 \text { if } Y_{i}^{*}>0 \text { where } Y_{i}^{*}=X_{i} \boldsymbol{\beta}+u_{1 i} \\
0 \text { if } Y_{i}^{*} \leq 0
\end{array}\right. \\
\operatorname{RESPOND} & =\left\{\begin{array}{l}
1 \text { if } W_{i}^{*}>0 \text { where } W_{i}^{*}=Z_{i} \boldsymbol{\gamma}+u_{2 i} \\
0 \text { if } W_{i}^{*} \leq 0
\end{array}\right. \\
\operatorname{CORR}\left(u_{1}, u_{2}\right) & =\rho
\end{aligned}
$$

where RENT is the dependent variable in the outcome equation; RESPOND is the dependent variable in the selection equation; the latent variables $Y_{i}^{*}$ and $W_{i}^{*}$ represent the expected utility gain from the land rental and survey response decisions, respectively; $\boldsymbol{\beta}$ and $\boldsymbol{\gamma}$ are parameters to be estimated; and $u_{1 i}$ and $u_{2 i}$ are error terms assumed to be normally distributed. The model permits a test of $\rho=0$ to evaluate if estimation of an ordinary probit without selection would yield biased coefficient estimates. This strategy allows us to control for observed factors that may shape response behavior, as captured in $Z$, as well as unobserved ones that could be correlated with the land rental decision. The unobserved factors are accounted for by the correlation of error terms across the two equations. With effective observed control variables, it is possible that the selection term $\rho$ may or may not be significant in the joint bivariate estimation.

Covariates $X$ and $Z$ include factors hypothesized to influence the land rental and survey response decisions, respectively, with specific variables to be included drawn from related CV studies and the agricultural technology adoption literature. Such factors typically include measures of farm size or scale of operation, demographic characteristics such as age and education level, current management practices, attitudinal measures, and farm specialization (e.g., income source) measures. These factors are applicable to the adoption of rotational grazing practices and have been included in previous analyses of MIG strategies on beef and dairy farms (Brock and Barham, 2009; Foltz and Lang, 2005; Gillespie et al., 2008; Jensen et al., 2015; Kim, Gillespie, and Paudel, 2005). Descriptions of the specific variables used to control for these factors in our analysis are introduced in Section 5. 


\section{Mail Survey of Beef Cattle Producers}

Information on producer willingness to rent public land for rotational grazing comes from a 2016 mail survey of Wisconsin beef cattle producers. The 2012 U.S. Census of Agriculture listed this population at 18,433 producers, and sample construction was based on a confidential list frame maintained by the USDA National Agricultural Statistics Service (NASS) regional field office in Des Moines, Iowa. The sampling procedure used a stratified design based on herd size and MIG practices. We defined seven herd size strata: less than 20 head, 2049 head, 50-99 head, 100-199 head, 200-499 head, 500-999 head, and more than 1,000 head. Designation as an MIG or non-MIG producer was based on whether producers used MIG practices as indicated in the 2012 U.S. Census of Agriculture (USDA-NASS, 2013). The final sample consisted of 1,172 producers, of whom $22 \%$ were MIG practitioners.

This analysis uses 105 observations from active producers who returned a completed survey, for an effective response rate of $16 \%$ after removing returns from ineligible members of the population. We suspect that the relatively low response rate stemmed from a combination of disinterest in grassland rental among non-MIG farmers and the inability to implement a third round of survey mailing because of institutional constraints. Among respondents, 59\% checked the MIG box in the census, which means that MIG producers were more than three times as likely to respond to our survey as non-MIG producers. The low overall response rate combined with the marked avidity effect for MIG producers affirms the need to consider nonrandom selection in our analysis.

Stated land rental intentions come from a CV module in the study questionnaire. It asked respondents whether they would rent public land for rotational grazing at a given land rental offer price. The module included an introduction, summary of grazing conditions, list of required inputs to be supplied by the producer, and contract length. Although rental decisions are complex, and require the producer to consider a variety of variables including distance from their farm and infrastructure availability, respondents receive sufficient details to allow them to form an expectation of profitability and other related trade-offs for their decision. We piloted the survey instrument with grazing experts and beef cattle producers.

Each questionnaire included two CV scenarios for rotational grazing: one for grass-dominant and another for shrub-dominant land types. The scenarios were posed to respondents independently such that they could choose to participate in one, both, or neither program. Respondents indicated their willingness to rent public land by agreeing to the given CV grazing scenario. Three questionnaire versions were used that varied only in terms of rental rate offer price. Each version had either low, medium, or high offer prices assigned at random across the sample. The offer prices ranged from a low of $\$ 10 /$ acre in both scenarios to a high of $\$ 40 /$ acre in the grass scenario and $\$ 30 /$ acre in the shrub scenario 
and were determined through conversations with cattle producers and grazing professionals in Wisconsin. The decision to rent was voluntary and elicited via dichotomous choice questions.

\section{Study Variables and Estimating Equations}

We estimate the probit model with and without selection for the grass and shrub CV scenarios separately, as well as for the pooled CV scenarios using maximum likelihood. The empirical specification is

$$
\begin{aligned}
\operatorname{Pr}(\text { RENT })= & \boldsymbol{\Phi}\left(\beta_{0}+\beta_{1} \text { PRICE }+\beta_{2} \text { HERDSIZE }+\beta_{3} M I G\right. \\
& +\beta_{4} \text { PASTURE }+\beta_{5} \text { INCFARM }+\beta_{6} \text { RENTHIST } \\
& \left.+\beta_{7} \text { AGE }+\beta_{8} \text { DIVERSE }+\beta_{9} \text { ATTITUDE }+u_{1}\right) \\
\operatorname{Pr}(\text { RESPOND })= & \boldsymbol{\Phi}\left(\gamma_{0}+\gamma_{1} \text { HERDSIZE }+\gamma_{2} M I G+\gamma_{3}\right. \text { PASTURE } \\
& \left.+\gamma_{4} \text { INCFARM }+\gamma_{5} \text { RENTHIST }+\gamma_{6} \text { AGE }+u_{2}\right),
\end{aligned}
$$

where $\boldsymbol{\Phi}$ is the cumulative distribution function of the standard normal distribution, and the expressions inside of parentheses determine the latent index variables $Y_{i}^{*}$ and $W_{i}{ }^{*}$ defined in equation (1), respectively. In addition to controlling for the survey response decision, we also evaluated whether dropping observations because of missing values for explanatory variables might affect our estimates but did not find support for this possibility. ${ }^{2}$

Median predicted values of WTP are recovered using the estimated coefficients from equation (2) as (Haab and McConnell, 2003) follows:

$$
\begin{aligned}
\text { WTP }= & {\left[\beta_{0}+\beta_{2} \overline{\text { HERDSIZE }}+\beta_{3} \overline{M I G}+\beta_{4} \overline{\text { PASTURE }}\right.} \\
& +\beta_{5} \overline{\overline{I N C F A R M}}+\beta_{6} \overline{\text { RENTHIST }}+\beta_{7} \overline{\text { AGE }}+\beta_{8} \overline{\text { DIVERSE }} \\
& \left.+\beta_{9} \overline{\text { ATTITUDE }}\right] / \beta_{1},
\end{aligned}
$$

where the bar above variable names denotes sample average values. To provide a measure of spread, we report the interquartile range for WTP values subsequently, recovered using individual values of the explanatory variables.

Variables are constructed using data from two sources. First, all explanatory variables in the RESPOND equation come from the USDA-NASS sample frame used to administer the mail survey (Table 1). The frame drew on the 2012 U.S. Census of Agriculture and included data for both respondents and nonrespondents. Therefore, no mail survey data were introduced at this stage beyond the response itself. Two variables pertain specifically to the livestock

2 We tested whether the proportion of respondents that agreed to rent public land for rotational grazing differed depending on whether the observation could be dropped because of a missing data point elsewhere. The $z$-statistic was not significant at a 0.05 level for either scenario. 
Table 1. Descriptive Statistics for Variables in the Selection Equation by Response Status ${ }^{\mathrm{a}}$

\begin{tabular}{|c|c|c|c|c|c|c|}
\hline \multirow[b]{2}{*}{ Variable } & \multicolumn{2}{|c|}{$\begin{array}{l}\text { Did Not Respond } \\
\qquad(\mathrm{N}=493)\end{array}$} & \multicolumn{2}{|c|}{$\begin{array}{l}\text { Did Respond } \\
\quad(\mathrm{N}=118)\end{array}$} & \multicolumn{2}{|c|}{$\begin{array}{l}\text { Difference } \\
\text { Test }^{\mathrm{b}}\end{array}$} \\
\hline & Mean & $\begin{array}{l}\text { Standard } \\
\text { Deviation }\end{array}$ & Mean & $\begin{array}{l}\text { Standard } \\
\text { Deviation }\end{array}$ & $\begin{array}{l}\text { Test } \\
\text { statistic }\end{array}$ & $P$ \\
\hline HERDSIZE & 265 & 535 & 195 & 219 & -1.389 & 0.1653 \\
\hline$M I G$ & 0.312 & 0.464 & 0.653 & 0.478 & $6.845^{* * *}$ & $<0.0001$ \\
\hline PASTURE & 116 & 268 & 162 & 204 & $1.749^{*}$ & 0.0809 \\
\hline INCFARM & 52.7 & 37.8 & 49.6 & 36.7 & -0.798 & 0.4249 \\
\hline RENTHIST & 0.160 & 0.367 & 0.737 & 0.442 & $12.658^{* * *}$ & $<0.0001$ \\
\hline$A G E$ & 54.3 & 11.8 & 55.9 & 11.2 & 1.397 & 0.1631 \\
\hline
\end{tabular}

${ }^{a}$ Data are drawn from the mail survey sample frame and were analyzed at the U.S. Department of Agriculture, National Agricultural Statistics Service regional field office in Des Moines, Iowa. The anonymity of producers selected into the sample frame was maintained throughout and the summary statistics reported here in order to summarize respondent characteristics in aggregate.

${ }^{\mathrm{b}}$ Difference tests for continuous variables evaluated the difference in means using $t$-statistics. Difference tests for binary variables evaluated the difference in proportions using $z$-statistics. Asterisks $\left({ }^{* * *},{ }^{* *},{ }^{*}\right)$ indicate significant differences at the $0.01,0.05$, and 0.10 levels, respectively.

enterprise-namely, herd size (HERDSIZE), which is included as a measure of operation size, and an indicator for whether the producer currently employs an MIG practice $(M I G)$. Another three variables relate to the farming operation more generally and include pasture area (PASTURE), the share of household income the producer receives from farming activities (INCFARM), and previous experience with land rental transactions (RENTHIST). Finally, we controlled for age $(A G E)$ as a demographic characteristic. To explore response behavior, we tested for differences in the descriptive statistics by response status, under the null that no differences exist. Test results reported in the last column of Table 1 confirm that significant differences do exist between respondent and nonrespondent characteristics. Notably, producers who currently practice MIG and have previous land rental experience and fewer pasture acres were more likely to respond. This suggests that nonrandom selection attributable to nonresponse or avidity behavior is present.

Second, variables in the RENT equation use data from the producer mail survey (Table 2). The dependent variable is constructed from responses to the $\mathrm{CV}$ land rental scenarios. We expect the CV land rental offer price (PRICE) to be negative in accordance with the law of demand. A measure of herd diversification (DIVERSE) is captured by an index variable that reflects the number of different cattle types managed within a producer's operation. We expect this index to have a negative effect on willingness to rent land for rotational grazing because of the added management complexity of diverse animal feeding demands. We also hypothesize that favorable attitudes toward public agencies involved in grassland management could positively influence the willingness to rent land for rotational 
Table 2. Descriptive Statistics for Variables in the Outcome Equation ${ }^{\mathrm{a}}$

\begin{tabular}{|c|c|c|c|c|c|c|}
\hline Variable & Definition & $\mathrm{N}$ & Mean & $\begin{array}{l}\text { Standard } \\
\text { Deviation }\end{array}$ & Minimum & Maximum \\
\hline \multicolumn{7}{|l|}{ Dependent variables } \\
\hline $\begin{array}{l}\text { ENROLL (Grass } \\
\text { scenario) }\end{array}$ & $\begin{array}{l}\text { Replied "yes" to land } \\
\text { rental offer (binary) }\end{array}$ & 104 & 0.308 & & 0 & 1 \\
\hline $\begin{array}{l}\text { ENROLL (Shrub } \\
\text { scenario) }\end{array}$ & $\begin{array}{l}\text { Replied "yes" to land } \\
\text { rental offer (binary) }\end{array}$ & 85 & 0.204 & & 0 & 1 \\
\hline \multicolumn{7}{|c|}{ Independent variables } \\
\hline $\begin{array}{c}\text { PRICE (Grass } \\
\text { scenario) }\end{array}$ & $\begin{array}{l}\text { Land rental offer price } \\
\quad(\$ / \text { acre })\end{array}$ & 104 & 26.1 & 12.1 & 10 & 40 \\
\hline $\begin{array}{l}\text { PRICE (Shrub } \\
\text { scenario) }\end{array}$ & $\begin{array}{l}\text { Land rental offer price } \\
\quad \text { (\$/acre) }\end{array}$ & 85 & 20.8 & 8.05 & 10 & 30 \\
\hline HERDSIZE & $\begin{array}{l}\text { Size of livestock herd } \\
\text { (head) }\end{array}$ & 105 & 150 & 150 & 7 & 795 \\
\hline MIG & $\begin{array}{l}\text { Practiced intensive } \\
\text { grazing (binary) }\end{array}$ & 105 & 0.586 & & 0 & 1 \\
\hline PASTURE & Pasture area (acres) & 105 & 104 & 120 & 0 & 650 \\
\hline INCFARM & $\begin{array}{r}\text { Income from farming } \\
\text { (percentage points) }\end{array}$ & 105 & 49.3 & 33.3 & 0 & 100 \\
\hline RENTHIST & $\begin{array}{l}\text { Has previously rented } \\
\text { land (binary) }\end{array}$ & 105 & 0.543 & & 0 & 1 \\
\hline$A G E$ & Age of operator (years) & 105 & 58.0 & 11.0 & 26 & 78 \\
\hline DIVERSE & $\begin{array}{l}\text { Herd diversification } \\
\quad \text { index (from } 1 \text { to } 6)^{c}\end{array}$ & 105 & 1.752 & 0.830 & 0 & 4 \\
\hline ATTITUDE & $\begin{array}{l}\text { Public agency index } \\
\quad(\text { from } 1 \text { to } 10)^{\mathrm{d}}\end{array}$ & 105 & 5.86 & 1.92 & 2 & 10 \\
\hline
\end{tabular}

${ }^{a}$ Data are from a 2016 mail survey of Wisconsin beef cattle producers.

${ }^{\mathrm{b}}$ Binary variables coded as $1=$ yes, $0=$ otherwise.

${ }^{c}$ Index constructed as the count of different cattle types currently managed within the operation among the following six choices: dry beef cows, cow-calf pairs, finish animals, young stock, dairy heifers, and other.

${ }^{\mathrm{d}}$ Index constructed as the sum of Likert-scale responses to two statements related to public agencies where the Likert values ranged from 1 (least favorable) to 5 (most favorable) and the statements were "I am interested in grazing public land" and "I am willing to work with a public agency, such as the Wisconsin Department of Natural Resources,” respectively.

grazing. To measure this, we created an attitude index (ATTITUDE) based on the responses to two Likert-type statements where higher scores reflect more favorable attitudes toward working with public land agencies.

The remaining variables in Table 2 are as previously defined. We expect MIG to have a positive effect on the willingness to rent public land because producers with previous MIG experience are already familiar with grazing plans and regimes and may perceive more value in public lands than would non-MIG operations. We expect PASTURE to negatively influence the willingness to rent public land for grazing because producers with more pasture area are less likely to be land constrained. Producers with a greater share of income from farming 
Table 3. Regression Results for Independent Estimation of the Selection Equation $(\mathrm{N}=611)$

\begin{tabular}{lcc}
\hline \hline & \multicolumn{2}{c}{ Dependent Variable: RESPOND } \\
\cline { 2 - 3 } Independent Variable & Coefficient $^{\mathrm{a}}$ & Marginal Effect $^{\mathrm{b}}$ \\
\hline HERDSIZEc & -0.0037 & 0.0005 \\
& $(0.0033)$ & $(0.0006)$ \\
MIG & $0.6090^{* * *}$ & $0.1170^{* * *}$ \\
& $(0.1390)$ & $(0.0254)$ \\
PASTURE & -0.0035 & 0.0007 \\
& $(0.0035)$ & $(0.0006)$ \\
INCFARM ${ }^{\mathrm{c}}$ & -0.0013 & -0.0026 \\
& $(0.0019)$ & $(0.0037)$ \\
RENTHIST & $1.5040^{* * *}$ & $0.2880^{* * *}$ \\
& $(0.1430)$ & $(0.0205)$ \\
AGE & 0.0084 & 0.0016 \\
& $(0.0060)$ & $(0.0011)$ \\
MALE & 0.0114 & 0.0022 \\
INTERCEPT & $(0.3570)$ & $(0.0683)$ \\
Log likelihood & $-2.0610^{* * *}$ & \\
LR chi-square\{7\} & $(0.5000)$ & \\
Pr [chi-square\{7\}] & -214.34 & \\
\hline \hline & 170.99 & \\
\hline
\end{tabular}

a Standard errors in parentheses. Asterisks $\left(* * *,{ }^{* *},{ }^{*}\right)$ indicate that the values are significant at the 0.01 , 0.05 , and 0.10 levels, respectively.

${ }^{\mathrm{b}}$ Marginal effects evaluated at sample means.

${ }^{c}$ Coefficients on HERDSIZE and INCFARM are scaled by a factor of 10 .

${ }^{\mathrm{d}}$ Model degrees of freedom in curly brackets and $P$ values in square brackets. LR, likelihood ratio.

have a greater dependence on these activities for their livelihood, and we expect INCFARM to positively influence the rental decision. Younger producers are typically more willing to adopt new technologies and practices as compared with older producers, and we expect $A G E$ to have a negative effect. Transaction costs associated with renting land for the first time (e.g., search costs, screening, contracting and legal advice, and negotiation) are high, and therefore, we expect RENTHIST to increase their willingness to participate in this market.

\section{Empirical Analysis and Results}

Before presenting our main, it is useful to focus on the issue of nonrandom selection. In Table 2, we observed significant differences in three descriptive characteristics associated with the response decisions of producers: MIG practices, previous land rental experience, and pasture area. Table 3 presents results for an independent probit estimation of the factors affecting response decisions. The results show that only the first two factors, MIG and previous rental experience, significantly influenced the decision to respond to the survey 
in a regression context, with both having a positive effect. None of the other factors, including pasture area, significantly predicted response.

Table 4 reports estimation results for the pooled CV scenarios. ${ }^{3}$ The model includes an additional indicator variable (SHRUB) to allow for differential intercept terms between the grass- and shrub-dominated scenarios. From the regression coefficients and marginal effect estimates, we extract three main observations. First, many of the estimates are statistically significant and have the expected signs in terms of predicting enrollment. These findings provide a useful basis for summarizing factors that positively shape the likelihood of participating in public land rentals. Second, the sign and statistical significance of the coefficient estimates in the outcome equation with and without nonrandom selection are nearly identical. Only for the age variable does the estimate go from being a statistically significant determinant of the land rental decision at conventional levels $(P<0.1)$ in the regression without selection to being statistically insignificant when controlling for selection. Moreover, none of the coefficient magnitudes change markedly across the regressions. Third, the coefficient estimate on the term controlling for nonrandom selection is not statistically significant, further confirming that the selection control is not vital to the results of this estimation. Overall, these results suggest that estimates of WTP reported later are based on robust predictors.

In Table 5, we report results for probit estimations with nonrandom selection for the grass and shrub CV scenarios, and noticeable differences between the two land rental options are evident. First, as one would expect for a demand estimate, the land rental price was negatively associated with stated land rental decisions for the shrub-dominant scenario. The sign on the grass-based scenario is also negative, but the coefficient estimate is not statistically significant. This could be related to the smaller sample sizes involved in separating the two regressions. Second, producers who will be most likely to participate in rental arrangements on grass-dominant lands also practice MIG, have positive attitudes toward public agencies, have larger operations in terms of herd size, are younger, and manage fewer types of cattle. Based on the marginal effects, MIG increases the probability of agreeing to rent public land for rotational grazing by 0.25 as compared with a non-MIG producer. Other things being equal, an increase in age significantly decreases this probability, whereas an increase in herd size significantly increases it but by much smaller magnitudes. Finally, increase in the types of cattle managed decreases the probability of a producer agreeing to rent public land by 0.25 .

These are substantive effects from a program design perspective. Arguably, the first two if not three characteristics could easily be identified by those knowledgeable about local cattle producers. Although the estimates with

3 To evaluate the data pooling, we conducted an initial Chow Test $[F(10,179)=0.349, P=0.966]$ and failed to reject at conventional significance levels. We also present results for the CV scenarios estimated separately in Table 5, to highlight their potential differences. 
Table 4. Regression Results with and without Nonrandom Selection, Pooled Contingent Valuation Scenarios

\begin{tabular}{|c|c|c|c|c|}
\hline \multirow[b]{2}{*}{ Variable } & \multicolumn{2}{|c|}{ Without Selection } & \multicolumn{2}{|c|}{ With Selection } \\
\hline & Coefficient $^{\mathrm{a}}$ & Marginal Effect ${ }^{\mathrm{b}}$ & Coefficient & Marginal Effect \\
\hline \multicolumn{5}{|c|}{ Outcome Equation, Dependent Variable: ENROLL $(\mathrm{N}=189)$} \\
\hline PRICE & $\begin{array}{c}-0.0346^{* * *} \\
(0.0124)\end{array}$ & $\begin{array}{c}-0.0072^{* * *} \\
(0.0024)\end{array}$ & $\begin{array}{c}-0.0358^{* * *} \\
(0.0136)\end{array}$ & $\begin{array}{c}-0.0072^{* * *} \\
(0.0027)\end{array}$ \\
\hline HERDSIZE ${ }^{\mathrm{c}}$ & $\begin{array}{l}0.0023^{* *} \\
(0.0011)\end{array}$ & $\begin{array}{c}0.0055^{* *} \\
(0.0021)\end{array}$ & $\begin{array}{c}0.0024^{* *} \\
(0.0114)\end{array}$ & $\begin{array}{l}0.0049^{* *} \\
(0.0022)\end{array}$ \\
\hline$M I G$ & $\begin{array}{l}0.6300^{* *} \\
(0.2620)\end{array}$ & $\begin{array}{c}0.1310^{* *} \\
(0.0532)\end{array}$ & $\begin{array}{l}0.6880^{* *} \\
(0.327)\end{array}$ & $\begin{array}{l}0.1390^{* *} \\
(0.0617)\end{array}$ \\
\hline PASTURE & $\begin{array}{r}-0.0016 \\
(0.0014)\end{array}$ & $\begin{array}{r}-0.0032 \\
(0.0029)\end{array}$ & $\begin{array}{r}-0.0016 \\
(0.0016)\end{array}$ & $\begin{array}{r}-0.0033 \\
(0.0031)\end{array}$ \\
\hline INCFARM ${ }^{\mathrm{c}}$ & $\begin{array}{c}-0.0093^{* *} \\
(0.0040)\end{array}$ & $\begin{array}{c}-0.0019^{* *} \\
(0.0008)\end{array}$ & $\begin{array}{c}-0.0152^{* * *} \\
(0.0047)\end{array}$ & $\begin{array}{c}-0.0031^{* * *} \\
(0.0009)\end{array}$ \\
\hline RENTHIST & $\begin{array}{l}1.0210^{* * *} \\
(0.289)\end{array}$ & $\begin{array}{l}0.2120^{* * *} \\
(0.0556)\end{array}$ & $\begin{array}{l}1.1150^{* * *} \\
(0.320)\end{array}$ & $\begin{array}{l}0.2250^{* * *} \\
(0.0638)\end{array}$ \\
\hline$A G E$ & $\begin{array}{r}-0.0194^{*} \\
(0.0116)\end{array}$ & $\begin{array}{r}-0.0040^{*} \\
(0.0024)\end{array}$ & $\begin{array}{r}-0.0183 \\
(0.0126)\end{array}$ & $\begin{array}{r}-0.0037 \\
(0.0026)\end{array}$ \\
\hline DIVERSE & $\begin{array}{c}-0.3650^{* *} \\
(0.1670)\end{array}$ & $\begin{array}{c}-0.0759^{* *} \\
(0.0334)\end{array}$ & $\begin{array}{c}-0.5470^{* * *} \\
(0.1840)\end{array}$ & $\begin{array}{c}-0.1100^{* * *} \\
(0.0351)\end{array}$ \\
\hline ATTITUDE & $\begin{array}{l}0.1700^{* * *} \\
(0.0658)\end{array}$ & $\begin{array}{c}0.0353^{* * *} \\
(0.0130)\end{array}$ & $\begin{array}{c}0.1540^{* *} \\
(0.0690)\end{array}$ & $\begin{array}{c}0.0311^{* *} \\
(0.0139)\end{array}$ \\
\hline$S H U R B$ & $\begin{array}{c}-0.6670^{* * *} \\
(0.2480)\end{array}$ & $\begin{array}{c}-0.1390^{* * *} \\
(0.0487)\end{array}$ & $\begin{array}{c}-0.7010^{* *} \\
(0.273)\end{array}$ & $\begin{array}{c}-0.1410^{* * *} \\
(0.0539)\end{array}$ \\
\hline INTERCEPT & $\begin{array}{c}0.2380 \\
(0.8210)\end{array}$ & & $\begin{array}{c}0.7960 \\
(0.9510)\end{array}$ & \\
\hline \multicolumn{5}{|c|}{ Selection Equation, Dependent Variable: RESPOND $(\mathrm{N}=611)$} \\
\hline Variable & & & Coefficient & \\
\hline$\overline{H E R D S I Z E}$ & & & $\begin{array}{r}-0.0022 \\
(0.0027)\end{array}$ & \\
\hline$M I G$ & & & $\begin{array}{c}0.6470^{* * *} \\
(0.1250)\end{array}$ & \\
\hline PASTURE & & & $\begin{array}{r}-0.0031 \\
(0.0029)\end{array}$ & \\
\hline INCFARM & & & $\begin{array}{r}-0.0011 \\
(0.0018)\end{array}$ & \\
\hline RENTHIST & & & $\begin{array}{l}1.5550^{* * *} \\
(0.1300)\end{array}$ & \\
\hline$A G E$ & & & $\begin{array}{c}0.0034 \\
(0.0054)\end{array}$ & \\
\hline INTERCEPT & & & $\begin{array}{c}-1.6350^{* * *} \\
(0.3250)\end{array}$ & \\
\hline$\rho$ & & & $\begin{array}{c}0.0119 \\
(0.3052)\end{array}$ & \\
\hline $\operatorname{Wald}(\rho)$ & & & 0.0015 & \\
\hline
\end{tabular}


Table 4. Continued

\begin{tabular}{lcc}
\hline \hline \multicolumn{2}{l}{ Selection Equation, Dependent Variable: RESPOND $(\mathrm{N}=611)$} & \\
\hline Variable & Coefficient $^{\mathrm{a}}$ & Coefficient \\
\hline $\operatorname{Pr}[$ Wald $(\rho)]$ & & {$[0.9689]$} \\
Log likelihood & -74.23 & -330.06 \\
${\text { Wald }\{9\}^{\mathrm{d}}}_{\operatorname{Pr}[\text { Wald }\{9\}]}$ & 81.96 & 44.20 \\
\hline \hline
\end{tabular}

a Standard errors in parentheses. Asterisks $\left({ }^{* * *},{ }^{* *},{ }^{*}\right)$ indicate that the values are significant at the 0.01 , 0.05 , and 0.10 levels, respectively.

$\mathrm{b}$ Marginal effects evaluated at sample means.

${ }^{c}$ Coefficients on HERDSIZE and INCFARM are scaled by a factor of 10.

${ }^{\mathrm{d}}$ Model degrees of freedom in curly brackets and $\mathrm{P}$ values in square brackets.

Table 5. Regression Results with Nonrandom Selection, by Grass and Shrub Contingent Valuation (CV) Scenario

\begin{tabular}{|c|c|c|c|c|}
\hline \multirow[b]{2}{*}{ Variable } & \multicolumn{2}{|c|}{ Grass CV Scenario $(\mathrm{N}=104)$} & \multicolumn{2}{|c|}{ Shrub CV Scenario $(\mathrm{N}=85)$} \\
\hline & Coefficient $^{\mathrm{a}}$ & Marginal Effect ${ }^{b}$ & Coefficient & Marginal Effect \\
\hline \multicolumn{5}{|c|}{ Outcome Equation, Dependent Variable: ENROLL } \\
\hline PRICE & $\begin{array}{c}-0.0242 \\
(0.0173)\end{array}$ & $\begin{array}{c}-0.0048 \\
(0.0032)\end{array}$ & $\begin{array}{c}-0.0867^{* *} \\
(0.0342)\end{array}$ & $\begin{array}{c}-0.0118^{* *} \\
(0.0055)\end{array}$ \\
\hline$H E R D S I Z E^{\mathrm{c}}$ & $\begin{array}{c}0.0028^{*} \\
(0.0016)\end{array}$ & $\begin{array}{c}0.0056^{*} \\
(0.0031)\end{array}$ & $\begin{array}{c}0.0032 \\
(0.0021)\end{array}$ & $\begin{array}{c}0.0044 \\
(0.0028)\end{array}$ \\
\hline$M I G$ & $\begin{array}{l}1.2760^{* *} \\
(0.5290)\end{array}$ & $\begin{array}{l}0.2530^{* * *} \\
(0.0881)\end{array}$ & $\begin{array}{c}0.8180 \\
(0.5820)\end{array}$ & $\begin{array}{c}0.1110 \\
(0.0719)\end{array}$ \\
\hline PASTURE & $\begin{array}{c}0.0018 \\
(0.0020)\end{array}$ & $\begin{array}{c}0.0035 \\
(0.0040)\end{array}$ & $\begin{array}{c}-0.0103^{* *} \\
(0.0044)\end{array}$ & $\begin{array}{c}-0.0014^{* *} \\
(0.0063)\end{array}$ \\
\hline$I N C F A R M^{\mathrm{c}}$ & $\begin{array}{c}-0.0167^{* *} \\
(0.0075)\end{array}$ & $\begin{array}{c}-0.0033^{* *} \\
(0.0013)\end{array}$ & $\begin{array}{c}-0.0235^{* * *} \\
(0.00910)\end{array}$ & $\begin{array}{c}-0.0032^{* *} \\
(0.0014)\end{array}$ \\
\hline RENTHIST & $\begin{array}{l}1.4940^{* * *} \\
(0.5060)\end{array}$ & $\begin{array}{l}0.2970^{* * *} \\
(0.0832)\end{array}$ & $\begin{array}{l}1.3150^{* *} \\
(0.6030)\end{array}$ & $\begin{array}{c}0.1790^{*} \\
(0.0942)\end{array}$ \\
\hline$A G E$ & $\begin{array}{c}-0.0407^{* *} \\
(0.0191)\end{array}$ & $\begin{array}{c}-0.0081^{* *} \\
(0.0036)\end{array}$ & $\begin{array}{c}0.0122 \\
(0.0225)\end{array}$ & $\begin{array}{c}0.0017 \\
(0.0031)\end{array}$ \\
\hline DIVERSE & $\begin{array}{c}-1.2450^{* * *} \\
(0.3660)\end{array}$ & $\begin{array}{c}-0.2470^{* * *} \\
(0.0536)\end{array}$ & $\begin{array}{c}-0.0379 \\
(0.2670)\end{array}$ & $\begin{array}{c}-0.00516 \\
(0.0363)\end{array}$ \\
\hline ATTITUDE & $\begin{array}{c}0.2420^{* *} \\
(0.1040)\end{array}$ & $\begin{array}{c}0.0481^{* *} \\
(0.0192)\end{array}$ & $\begin{array}{c}0.1900 \\
(0.1350)\end{array}$ & $\begin{array}{c}0.0259 \\
(0.0196)\end{array}$ \\
\hline INTERCEPT & $\begin{array}{c}1.6610 \\
(1.3340)\end{array}$ & & $\begin{array}{c}-1.5190 \\
(1.689)\end{array}$ & \\
\hline
\end{tabular}


Table 5. Continued

\begin{tabular}{|c|c|c|}
\hline Variable & Coefficient & Coefficient \\
\hline \multicolumn{3}{|c|}{ Selection Equation, Dependent Variable: $\operatorname{RESPOND}(\mathrm{N}=611)$} \\
\hline HERDSIZE & $\begin{array}{r}-0.0016 \\
(0.0031)\end{array}$ & $\begin{array}{r}-0.0018 \\
(0.0033)\end{array}$ \\
\hline$M I G$ & $\begin{array}{l}0.5900^{* * *} \\
(0.1510)\end{array}$ & $\begin{array}{l}0.5700^{* * *} \\
(0.1550)\end{array}$ \\
\hline PASTURE & $\begin{array}{r}-0.0038 \\
(0.0036)\end{array}$ & $\begin{array}{r}-0.0030 \\
(0.0036)\end{array}$ \\
\hline INCFARM & $\begin{array}{r}-0.0009 \\
(0.0021)\end{array}$ & $\begin{array}{r}-0.0020 \\
(0.0022)\end{array}$ \\
\hline RENTHIST & $\begin{array}{l}1.4640^{* * *} \\
(0.1560)\end{array}$ & $\begin{array}{l}1.4740^{* * * *} \\
(0.1610)\end{array}$ \\
\hline$A G E$ & $\begin{array}{c}0.0037 \\
(0.0066)\end{array}$ & $\begin{array}{c}0.0037 \\
(0.0066)\end{array}$ \\
\hline INTERCEPT & $\begin{array}{c}-1.9580^{* * *} \\
(0.3980)\end{array}$ & $\begin{array}{c}-1.9410^{* * *} \\
(0.3990)\end{array}$ \\
\hline$\rho$ & $\begin{array}{r}-0.1942 \\
(0.4131)\end{array}$ & $\begin{array}{c}0.3152 \\
(0.5436)\end{array}$ \\
\hline $\operatorname{Wald}(\rho)$ & 0.2031 & 0.3198 \\
\hline $\operatorname{Pr}[\operatorname{Wald}(\rho)]$ & {$[0.6522]$} & {$[0.5717]$} \\
\hline Log likelihood & -210.32 & -196.12 \\
\hline Wald $\{9\}^{\mathrm{d}}$ & 22.1 & 15.85 \\
\hline $\operatorname{Pr}[$ Wald $\{9\}]$ & {$[0.0086]$} & {$[0.0701]$} \\
\hline
\end{tabular}

a Standard errors in parentheses. Asterisks $(* * *, * *, *)$ indicate that the values are significant at the 0.01 , 0.05 , and 0.10 levels, respectively.

${ }^{\mathrm{b}}$ Marginal effects evaluated at sample means.

${ }^{\mathrm{c}}$ Coefficients on HERDSIZE and INCFARM are scaled by a factor of 10 .

${ }^{\mathrm{d}}$ Model degrees of freedom in curly brackets and $P$ values in square brackets.

nonrandom selection are again not statistically significant in either regression, they exhibit opposite signs, negative in the grasslands and positive in the shrub land rental. Furthermore, the Wald tests for overall model fit in the three main sets of regressions are significant at the 0.05 level across the pooled model and the grasslands model but not for the shrub-dominant scenario.

Because of the distinctive results across the pooled and separate land type CV scenarios, we present WTP derived from all three cases in Table 6. The first row reports overall median WTP values for the pooled CV scenarios with and without selection. Notably, the estimated median values are negative with only a slight difference in magnitude of $\$ 0.27$, implying that less than half of producers will have a positive WTP to rent public grazing land. Sensitivity analysis was performed to condition WTP values by MIG and previous land rental experience. The more striking results are WTP estimates based on whether the respondents practice MIG and have previous rental experience for the grassdominant scenario. In those cases, the WTP estimates move substantially into the 
Table 6. Willingness-to-Pay (WTP) to Rent Public Land for Rotational Grazing by Contingent Valuation Scenario (\$/acre)

\begin{tabular}{|c|c|c|c|c|}
\hline \multirow[b]{2}{*}{$\begin{array}{l}\text { Sensitivity } \\
\text { Analysis }\end{array}$} & \multirow{2}{*}{$\begin{array}{l}\begin{array}{l}\text { Probit without } \\
\text { Selection }\end{array} \\
\text { Pooled } \\
\text { Scenario }\end{array}$} & \multicolumn{3}{|c|}{$\begin{array}{l}\text { Probit with } \\
\text { Selection }\end{array}$} \\
\hline & & $\begin{array}{l}\text { Pooled } \\
\text { Scenarios }\end{array}$ & $\begin{array}{l}\text { Grass } \\
\text { Scenario }\end{array}$ & $\begin{array}{l}\text { Shrub } \\
\text { Scenario }\end{array}$ \\
\hline \multicolumn{5}{|l|}{ Overall median WTP: } \\
\hline $\begin{array}{l}\text { At sample means } \\
\text { Interquartile range }\end{array}$ & $\begin{array}{l}-5.40^{\mathrm{a}} \\
(-20.45,13.07)\end{array}$ & $\begin{array}{l}-5.13 \\
(-21.25,19.42)\end{array}$ & $\begin{array}{l}-4.95 \\
(-39.85,48.84)\end{array}$ & $\begin{array}{l}-3.67 \\
(-8.67,12.95)\end{array}$ \\
\hline \multicolumn{5}{|l|}{ Median WTP by sensitivity analysis: } \\
\hline \multicolumn{5}{|c|}{ By management intensive grazing (MIG) experience } \\
\hline$M I G=1$ & 2.14 & 2.82 & 16.88 & 0.24 \\
\hline$M I G=0$ & -16.07 & -16.39 & -35.85 & -9.19 \\
\hline \multicolumn{5}{|l|}{ By land rental experience } \\
\hline RENTHIST $=1$ & 8.09 & 9.1 & 23.26 & 3.27 \\
\hline RENTHIST $=0$ & -21.42 & -22.04 & -38.47 & -11.90 \\
\hline \multicolumn{5}{|l|}{ By MIG and land rental experience } \\
\hline$M I G=1 \&$ RENTHIST $=1$ & 15.63 & 17.06 & 45.09 & 7.17 \\
\hline$M I G=0 \&$ RENTHIST $=0$ & -32.09 & -33.31 & -69.37 & -17.43 \\
\hline
\end{tabular}

${ }^{a}$ WTP values evaluated at mean values of explanatory variables except where noted.

positive range, to $\$ 16.88$ per acre for MIG, $\$ 23.26$ per acre for rental experience, and $\$ 45.09$ for acre for producers with both MIG and land rental experience. A much smaller shift is evident in the shrub scenario, with the highest WTP estimate being just over $\$ 7$ per acre for respondents with MIG and previous land rental experience. The results from this table provide a magnified view of the avidity effect in terms of WTP.

\section{Discussion and Implications}

We highlight several policy implications from our results. First, we find that the median beef cattle producer has a negative WTP and is therefore unwilling to rent public land for rotational grazing. This relatively low overall interest at the prices offered implies that the expected benefits gained do not exceed costs for most producers. Additional subsidies or cost sharing might be needed to increase participation rates in rotational grazing programs on public lands and would contribute to overall program feasibility. Whereas some respondents likely decided against renting public grazing lands because they are not interested in adopting rotational grazing practices in general, others who may indeed be interested likely declined because they found the expected costs (e.g., water, temporary fencing, and/or transportation costs) of rental agreements on public lands too prohibitive as compared with private land rental. For instance, among producers who indicated some willingness to rent land and responded to survey 
debriefing questions, only $15 \%-30 \%$ would remain committed to their stated land rental decision if they needed to purchase and install fencing. Additional research to value the ecological services that rotational grazing provides to grasslands and society more generally could help boost public support for subsidy or cost-share programs and increase overall economic efficiency.

Second, as evidenced by survey response rates and much higher WTP estimates, Wisconsin producers most likely to be interested in public land rental opportunities are those that practice MIG and have prior rental experience. Indeed, for grasslands, they were the main class of respondents for whom WTP values were positive. Notably, we estimated median WTP values for this group to be $\$ 45 /$ acre, whereas the statewide average pasture rental rate in Wisconsin for 2016 was \$35/acre (USDA-NASS, 2016). Without the interest of these groups, a grazing program on public land in Wisconsin might not be successful. Not surprisingly perhaps is our conclusion that Wisconsin DNR and other public agencies interested in starting public grazing programs should target efforts toward MIG producers already active in land rental markets. In the longer term, they can also work with extension agents, grazing brokers, and other grazing specialists to build producer capacity for practicing MIG on private landholdings, which may in turn increase overall interest in participating in a public grazing program.

Finally, similar to other ex ante technologies, the successful diffusion of grazing programs on public lands will depend on both the physical and economic availability of these lands (Barham, Mooney, Swinton, 2016). Whether sufficient producers with enough interest in renting public lands operate within a close distance to where most public grazing land is located remains an open question. Based on physical inventories of potential sites, most potential grazing lands are in the western, central, and southwestern regions of Wisconsin. These regions also boast sizable populations of beef and other nondairy cattle producers according to the U.S. Census of Agriculture. Furthermore, survey respondents who agreed to rent in the grass-dominant scenario indicated they are willing to travel for access to rented grazing land, with greater than $50 \%$ willing to travel 20 miles or more at our medium rental price level. As such, we are cautiously optimistic about the logistical feasibility of such grazing initiatives. Future research should explore whether such ex ante decisions might depend on one another in a spatial context (Lewis, Barham, and Robinson, 2011; Skevas, Skevas, and Swinton, 2018).

\section{Conclusions}

This article contributes to economic literature on ex ante analysis of agricultural production practices, technologies, and management strategies by examining the effect of survey response behavior on Wisconsin beef cattle producers' willingness to rent public land for rotational grazing. Our econometric model controls for 
nonrandom selection attributable to nonresponse and avidity effects driven by whether the producers followed an MIG practice in their current operation and had previous land rental experience. Even though the regressions were not particularly sensitive to selection issues in our estimations, we encourage attention to this issue in other ex ante contexts. The same factors that influenced producers' response behavior also played a significant role in their stated land rental intentions and suggests that bias could easily arise in other circumstances.

Grass-dominant land was the more popular of the two types of land that producers were asked to consider. For that rental opportunity, we expect younger producers with larger farms and less diverse cattle operations to be interested, especially among those practicing MIG already. The median WTP to rent public land in the grass-dominant scenario was $\$ 45 /$ acre, for those already practicing MIG and participating in land rental markets, which was above the Wisconsin statewide average rental rate of \$35/acre in 2016, and suggests such scenarios may be viable. For public grassland managers interested in promoting grazing as a sustainable management practice on public land, this suggests they could target initial outreach efforts at these types of producers with assistance from extension agents and grazing networks.

For shrub-dominant land, the median WTP was much lower, at under \$4/acre. Based on regression estimates, we expect producers with less pasture in their possession to be more interested in participating. Here, tailoring recruitment efforts might be a bit more difficult because those factors are less easily observed. However, they might become more feasible as discussions with producers advance with respect to public grassland rentals. Our results also show that grazing decisions extend beyond simple price considerations. Younger producers, for example, may have specific constraints or interest in expansion that make them more likely to seek grass-dominant rental opportunities. In general, producers will make their rental decision based on their own operational context - the size of their operation, how many pasture acres they own (and therefore need to rent), and how many different types of cattle they must manage.

For policy makers, this reflects a need for flexibility with regard to contract design. To entice producers to rent shrub-dominant land, additional incentives may be needed-for example, lower rental rates, longer contracts, or more favorable cost-share agreements for fencing inputs or transportation expenses. Additional research should revolve around producer willingness to travel to graze public land and the technical feasibility that assesses where this public land is located and how many grazers are located nearby to address viability concerns.

\section{References}

Barham, B. "Adoption of a Politicized Technology: bST and Wisconsin Dairy Farmers." American Journal of Agricultural Economics 78,4(1996):1056-63. 
Barham, B., D. Mooney, and S. Swinton. "Inconvenient Truths about Landowner (Un) Willingness to Grow Dedicated Bioenergy Crops.” Choices 31,4(2016):1-8.

Barry, S. "Current Findings on Grazing Impacts: California's Special Status Species Benefit from Grazing." California Cattleman, June 2011, 18-20.

Brock, C., and B. Barham. "Farm Structural Change of a Different Kind: Alternative Dairy Farms in Wisconsin-Graziers, Organic and Amish." Renewable Agriculture and Food Systems 24,1(2009):25-37.

Carson, R., N. Flores, and N. Meade. "Contingent Valuation: Controversies and Evidence." Environmental and Resource Economics 19,2(2001):173-210.

Cooper, J. "Combining Actual and Contingent Behavior Data to Model Farmer Adoption of Water Quality Protection Practices.” Journal of Agricultural and Resource Economics 22,1(1997):30-43.

Cooper, J., and R. Keim. "Incentive Payments to Encourage Farmer Adoption of Water Quality Protection Practices." American Journal of Agricultural Economics 78,1(1996):54-64.

Dalecki, M., J. Whitehead, and G. Blomquist. "Sample Non-response Bias and Aggregate Benefits in Contingent Valuation: An Examination of Early, Late and Non-respondents.” Journal of Environmental Management 38,2(1993):133-43.

DeVore, B. "Grazing as a Public Good in Western Minnesota." Land Stewardship Letters 32,1(2014):24-25. Internet site: landstewardshipproject.org/repository/1/1168/ no_1_ 2014_lsl.pdf (Accessed September 2017).

Dillman, D., J. Smyth, and L. Christian. Internet, Phone, Mail, and Mixed-mode Surveys: The Tailored Design Method. Hoboken, NJ: John Wiley and Sons, 2014.

Edwards, S., and G. Anderson. "Overlooked Biases in Contingent Valuation Surveys: Some Considerations.” Land Economics 63,2(1987):168-78.

Ethier, R., G. Poe, W. Schulze, and J. Clark. "A Comparison of Hypothetical Phone and Mail Contingent Valuation Responses for Green-Pricing Electricity Programs.” Land Economics 76,1(2000):54-67.

Foltz, J., and G. Lang. "The Adoption and Impact of Management Intensive Rotational Grazing (MIRG) on Connecticut Dairy Farms.” Renewable Agriculture and Food Systems 20,4(2005):261-66.

Frisina, M., and F. Morin. Grazing Private and Public Land to Improve the Fleecer Elk Winter Range. Rangelands 13,6(1991):291-94.

Gardner, B. "Some Implications of Federal Grazing, Timber, Irrigation, and Recreation Subsidies." Choices 12,3(1997):9-14.

Gillespie, J., W. Wyatt, B. Venuto, D. Blouin, and R. Boucher. "The Roles of Labor and Profitability in Choosing a Grazing Strategy for Beef Production in the US Gulf Coast Region.” Journal of Agricultural and Applied Economics 40,1(2008):301-13.

Groves, R. "Nonresponse Rates and Nonresponse Bias in Household Surveys." Public Opinion Quarterly 70,5(2006):646-75.

Haab, T, . and K. McConnell. The Econometrics of Non-market Valuation. Northampton, MA: Edward Elgar, 2003.

Hanemann, W. "Welfare Evaluations in Contingent Valuation Experiments with Discrete Responses." American Journal of Agricultural Economics 66,3(1984):332-41.

Harrington, J., and E. Kathol. "Responses of Shrub Midstory and Herbaceous Layers to Managed Grazing and Fire in a North American Savanna (Oak Woodland) and Prairie Landscape." Restoration Ecology 17,2(2009):234-44.

Heckman, J. “Sample Selection Bias as a Specification Error.” Econometrica 47,4(1979):15361. 
Hubbard, R., G. Newton, and G. Hill. "Water Quality and the Grazing Animal.” Journal of Animal Science 82,S13(2004):E255-63.

Hubbell, B., M. Marra, and G. Carlson. "Estimating the Demand for a New Technology: Bt Cotton and Insecticide Policies." American Journal of Agricultural Economics 82,1(2000):118-32.

Hudson, D., L.-H. Seah, D. Hite, and T. Haab. "Telephone Presurveys, Self-Selection, and Nonresponse Bias to Mail and Internet Surveys in Economic Research." Applied Economics Letters 11,4(2004):237-40.

Jensen, K., D. Lambert, C. Clark, C. Holt, B. English, J. Larson, T. Yu, and C. Hellwinckel. "Cattle Producers' Willingness to Adopt or Expand Prescribed Grazing in the United States." Journal of Agricultural and Applied Economics 47,2(2015):213-42.

Johansen, K. "Greener Pastures." Wisconsin Natural Resources 17(April 2017):17-19. Internet site: http://dnr.fiwi.gov/wnrmag/2017/04/Grazing.PDF (Accessed September 2017).

Kim, S., J. Gillespie, and K. Paudel. "The Effect of Socioeconomic Factors on the Adoption of Best Management Practices in Beef Cattle Production." Journal of Soil and Water Conservation 60,3(2005):111-20.

Kling, C., D. Phaneuf, and J. Zhao. "From Exxon to BP: Has Some Number Become Better Than No Number?" Journal of Economic Perspectives 26,4(2012):3-26.

Kloppenburg, J., R. Cates, R. Gildersleeve, D. Johnson, K. Mahalko, L. Paine, and S. Thomforde. Growing Wisconsin's Grazing Future. Blue Sky Greener Pastures Steering Committee. Blue Sky Greener Pastures Steering Committee, July 2012. Internet site: https://www.cias.wisc.edu/fiwp-content/uploads/2012/07/blueskygreenerpastweb. pdf (Accessed September 2017).

Lahaut, V., H. Jansen, D. van de Mheen, H. Garretsen, J. Verdurmen, and A. Van Dijk. "Estimating Non-response Bias in a Survey on Alcohol Consumption: Comparison of Response Waves." Alcohol and Alcoholism 38,2(2003):128-34.

Lewis, D., B. Barham, and B. Robinson. "Are There Spatial Spillovers in the Adoption of Clean Technology? The Case of Organic Dairy Farming." Land Economics 87,2(2011):25067.

Little, R. "A Test of Missing Completely at Random for Multivariate Data with Missing Values." Journal of the American Statistical Association 83,404(1998):1198-202.

Loomis, J. "Expanding Contingent Value Sample Estimates to Aggregate Benefit Estimates: Current Practices and Proposed Solutions." Land Economics 63,4(1987):396-402.

Ma, S., S. Swinton, F. Lupi, and C. Jolejole-Foreman. "Farmers' Willingness to Participate in Payment-for-Environmental-Services Programmes." Journal of Agricultural Economics 63,3(2012):604-26.

Melkonyan, T., and M. Taylor. "Regulatory Policy Design for Agroecosystem Management on Public Rangelands.” American Journal of Agricultural Economics 95,3(2013):606-27.

Messonnier, M., J. Bergstrom, C. Cornwell, R. Teasley, and H. Cordell. "Survey ResponseRelated Biases in Contingent Valuation: Concepts, Remedies, and Empirical Application to Valuing Aquatic Plant Management." American Journal of Agricultural Economics 82,2(2000):438-50.

Mitchell, R., and R. Carson. Using Surveys to Value Public Goods: The Contingent Valuation Method. Washington, DC: Resources for the Future, 1989.

Mooney, D., B. Barham, and C. Lian. "Inelastic and Fragmented Farm Supply Response for Second-Generation Bioenergy Feedstocks: Ex Ante Survey Evidence from Wisconsin.” Applied Economic Perspectives and Policy 37,2(2015):287-310. 
Paine, L., and R. Gildersleeve. A Summary of Beef Grazing Practices in Wisconsin. Madison: College of Agricultural and Life Sciences, University of WisconsinMadison, 2011. Internet site: https://www.cias.wisc.edu/wp-content/uploads/2018/05/ 2011-Dairy-Grazing-Summary.pdf (Accessed July 7, 2018).

Peress, M. “Correcting for Survey Nonresponse Using Variable Response Propensity.” Journal of the American Statistical Association 105,492(2010):1418-30.

Qaim, M., and A. de Janvry. "Genetically Modified Crops, Corporate Pricing Strategies, and Farmers' Adoption: The Case of Bt Cotton in Argentina." American Journal of Agricultural Economics 85,4(2003):814-28.

Robinson, C. "Opportunities and Challenges with Grazing Public Grassland in Wisconsin: The Producer Perspective.” Master's thesis, University of Wisconsin-Madison, 2017.

Singerman, A., and P. Useche. "Florida Citrus Growers' First Impressions on Genetically Modified Trees.” AgBioForum 20,1(2017):67-83.

Skevas, T., N. Hayden, S. Swinton, and F. Lupi. "Landowner Willingness to Supply Marginal Land for Bioenergy Production." Land Use Policy 50(January 2016):507-17.

Skevas, T., I. Skevas, and S. Swinton. "Does Spatial Dependence Affect the Intention to Make Land Available for Bioenergy Crops?” Journal of Agricultural Economics 69,2(2018):393-412.

Studer, J., S. Baggio, M. Mohler-Kuo, P. Dermota, J. Gaume, N. Bertholet, J. Daeppen, and G. Gmel. "Examining Non-response Bias in Substance Use Research-Are Late Respondents Proxies for Non-respondents?” Drug and Alcohol Dependence 132,12(2013):316-23.

Sulak, A., and L. Huntsinger. "Public Land Grazing in California: Untapped Conservation Potential for Private Lands? Working Landscapes May Be Linked to Public Lands.” Rangelands 29,3(2007):9-12.

Swinton, S., S. Tanner, B. Barham, D. Mooney, and T. Skevas. "How Willing Are Landowners to Supply Land for Bioenergy Crops in the Northern Great Lakes Region?" Global Change Biology-Bioenergy 9,2(2017):414-28.

Tsikriktsis, N. "A Review of Techniques for Treating Missing Data in OM Survey Research.” Journal of Operations Management 24,1(2005):53-62.

Undersander, D., B. Albert, D. Cosgrove, D. Johnson, and P. Peterson. Pastures for Profit: A Guide to Rotational Grazing. Madison: University of Wisconsin Extension, Publication A3529, 2011. Internet site: https://www.nrcs.usda.gov/Internet/FSE_DOCUMENTS/ stelprdb1097378.pdf (Accessed September 2017).

U.S. Bureau of Land Management. BLM's Management of Livestock Grazing. Unnumbered Fact Sheet, 2016. Internet site: https://www.blm.gov/sites/blm.gov/files/documents/ files/fiGrazingInfographic100516FINAL\%20\%281\%29\%20\%282\%29.pdf (Accessed June 2017).

U.S. Department of Agriculture, National Agricultural Statistics Service (USDA-NASS). 2012 U.S. Census of Agriculture. Washington, DC: USDA-NASS, 2013.

- 2016 Cash Rent Survey. Washington, DC: USDA-NASS, 2016.

Van de Ven, W., and B. Van Praag. "The Demand for Deductibles in Private Health Insurance: A Probit Model with Sample Selection.” Journal of Econometrics 17,2(1981): 229-52.

Whitehead, J., G. Blomquist, T. Hoban, and W. Clifford. "Assessing the Validity and Reliability of Contingent Values: A Comparison of On-Site Users, Off-Site Users, and Non-users." Journal of Environmental Economics and Management 29,2(1995): 238-51. 
Whitehead, J., and T. Cherry. "Willingness to Pay for a Green Energy Program: A Comparison of Ex-Ante and Ex-Post Hypothetical Bias Mitigation Approaches.” Resource and Energy Economics 29,4(2007):247-61.

Whitehead, J., P. Groothuis, and G. Blomquist. "Testing for Non-response and Sample Selection Bias in Contingent Valuation: Analysis of a Combination Phone/Mail Survey." Economics Letters 41,2(1993):215-20.

Whittlesey, N., R. Huffaker, and W. Butcher. "Grazing Policy on Public Lands.” Choices 8,3(1993):15-19. 